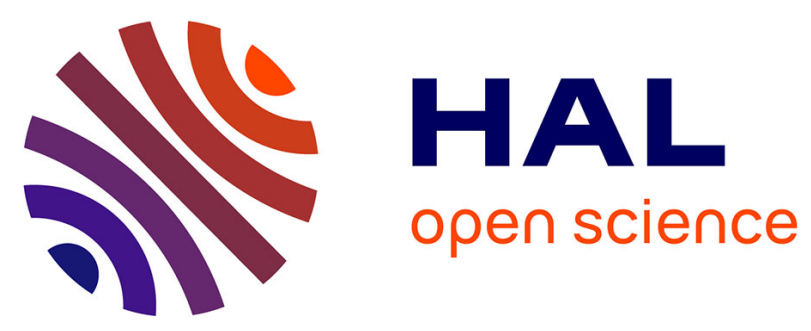

\title{
Biomarker responses in wild three-spined stickleback (Gasterosteus aculeatus L) as a useful tool for freshwater biomonitoring: a multiparametric approach
} Wilfried Sanchez, Ioanna Katsiadaki, Benjamin Piccini, Jean-Maxence Ditche, Jean-Marc Porcher

\section{To cite this version:}

Wilfried Sanchez, Ioanna Katsiadaki, Benjamin Piccini, Jean-Maxence Ditche, Jean-Marc Porcher. Biomarker responses in wild three-spined stickleback (Gasterosteus aculeatus L) as a useful tool for freshwater biomonitoring: a multiparametric approach. Environment International, 2008,34 (4), pp.490-498. 10.1016/j.envint.2007.11.003 . ineris-00961922

HAL Id: ineris-00961922

https://hal-ineris.archives-ouvertes.fr/ineris-00961922

Submitted on 20 Mar 2014

HAL is a multi-disciplinary open access archive for the deposit and dissemination of scientific research documents, whether they are published or not. The documents may come from teaching and research institutions in France or abroad, or from public or private research centers.
L'archive ouverte pluridisciplinaire HAL, est destinée au dépôt et à la diffusion de documents scientifiques de niveau recherche, publiés ou non, émanant des établissements d'enseignement et de recherche français ou étrangers, des laboratoires publics ou privés. 
Biomarker responses in wild three-spined stickleback (Gasterosteus aculeatus L.) as a useful tool for freshwater biomonitoring : a multiparametric approach

Wilfried Sanchez ${ }^{1 *}$, Ioanna Katsiadaki ${ }^{2}$, Benjamin Piccini ${ }^{1}$, Jean-Maxence Ditche ${ }^{3}$ and Jean-Marc Porcher ${ }^{1}$

${ }^{1}$ Institut National de 1'Environnement Industriel et des Risques (INERIS), Unité d'Evaluation des Risques Ecotoxicologiques, BP2, 60550, Verneuil-en-Halatte, France

${ }^{2}$ Centre for Environment, Fishreries and Aquaculture Science (Cefas), Barrack Road, The Nothe, Weymouth, Dorset, DT4 8UB, United Kingdom

${ }^{3}$ Office National de l'Eau et des Milieux Aquatiques, 60200 Compiègne, France

* Corresponding author. Tel : +33 (0)3 44618121 ; Fax: +33 (0)3 44556767

E-mail address : Wilfried.Sanchez@ineris.fr (W. Sanchez) 


\begin{abstract}
The biochemical response of wild sticklebacks collected in Autumn 2005 at seven stations in the North of France was studied using a set of complementary biomarkers. Here, data on biotransformation of xenobiotics, oxidative stress exposure and damages, neurotoxicity and endocrine disruption are provided. All the sites are characterized by a specific response pattern that allows distinguishing sampling locations. Moreover, these responses are in accordance with data on existing environmental pressures and the chemical analysis of metals performed in surface water. The assessment of individual responses is completed by fish population disturbance monitoring. Based on these measurements, the investigated sites are characterized by different levels of disturbance. This study argues for a multi-parametric approach of aquatic ecosystem contamination based on association between chemical, biochemical and ecological endpoints and provides a testimony of the usefulness of stickleback for this purpose.
\end{abstract}

Key-words : three-spined stickleback ; biomarkers ; fish ; biotransformation enzymes ; oxidative stress ; neurotoxicity ; endocrine disruption, field study 


\section{Introduction}

Water quality of aquatic ecosystems is assessed using a combination of chemical and ecological methods. Chemical monitoring is based on quantification of pollutant groups in water, sediments and biota. This targeted approach provides a valuable information on media contamination by a limited number of chemicals but it is not integrative since the effects of contamination on aquatic organisms are not considered (Amiard et al., 1998). Ecological monitoring is based on community structure assessment in various taxonomic assemblages including diatoms (Prygiel, 2002), oligochaetes (Prygiel et al., 1999) and fish (Oberdorff et al., 2002). These methods allow to detect adverse ecological effects but they respond to various disturbances acting at the community level and they are no reliable indicators of ecological impairment caused by specific contaminants (Amiard et al., 1998).

To assess the effects of contamination at low organisation levels, several studies have focused on biomarker utilisation as indicators of chemical exposure and early responses of aquatic organisms. Biomarkers are defined as observable or measurable modifications at the molecular, biochemical, cellular, physiological or behavioural levels revealing the exposure of an organism to xenobiotics (Lagadic et al., 1997). To evaluate the various responses to pollutant mixtures in organisms, the usefulness of a set of complementary biomarkers has been demonstrated and is now applied in environmental biomonitoring programs (Flammarion et al., 2002b; Schmitt et al., 2005; Triebskorn et al., 2001).

In this study, we have selected the three-spined stickleback (Gasterosteus aculeatus L.) as sentinel fish species. This is a small size fish widely distributed in European waters including fresh, estuarine and coastal waters, and characterised by a relatively sedentary 
behaviour. The stickleback is a well-studied model for biologists since their behaviour, ecology and evolution have been extensively characterised. Moreover, this is the only species with a quantifiable androgen and anti-androgen biomarker : the spiggin (Katsiadaki et al., 2002a). This androgen-induced glue protein is synthetised by the kidney (Jakobsson et al., 1999). In environmental toxicology, stickleback is also considered as a valuable model species that enable the measurement of both biochemical and physiological responses to pollutants such as metals (Sanchez et al., 2005), pesticides (Katsiadaki et al., 2006; Sanchez et al., 2006; Wogram et al., 2001), halogenated organic compounds (Holm et al., 1994) and steroids (Pottinger et al., 2002; Sebire et al., 2007). Stickleback biomarker responses can also be used for the biomonitoring of freshwater ecosystem contamination as previously described for cholinesterase activities (Sturm et al., 2000) and liver histology (Handy et al., 2002). More recently, we have demonstrated the potential of using the stickleback as a sentinel fish species to assess sublethal stress in multipollution context using a set of biochemical biomarkers (Sanchez et al., 2007).

The present study was designed to evaluate the use of a suite of biomarkers in stickleback as an early warning system for aquatic contamination. For this purpose, we used a set of parameters including biochemical biomarkers and biometrical measurements to characterise the various contaminated study sites. The investigated endpoints were selected in order to represent several biological processes. These included xenobiotic biotransformation activities such as 7-ethoxyresorufin-O-deethylase (EROD) and glutathione-S-transferase (GST), and neurotoxicity of pollutants with acetylcholinesterase (AChE) activity in the muscle. Antioxidants such as glutathione peroxidase (GPx), total glutathione content (GSH) and oxidative damages with 
thiobarbituric acid reactive substances (TBARS) were also studied. Vitellogenin (VTG) and spiggin (SPG) concentrations in males and females respectively were measured to evaluate exposure to endocrine disrupter compounds. Physiological parameters such as liver and gonad somatic index (HSI and GSI respectively) and condition factor (CF) were also determined. The biomarker measurements were complemented with (1) assessment of water quality of sampled sites based on physico-chemical characterisation and metal quantification; and (2) analysis of fish assemblage disturbances.

\section{Materials and methods}

\subsection{Site descriptions}

Fish were collected from 7 sites (Table 1) located in the North of France and characterised by the presence of wild stickleback populations. To reduce variations due to geographical factors, sampling sites were selected within the same hydro-ecoregion (Wasson et al., 2002). These sites were selected in order to assess the effects of various qualitative and quantitative impacts on stickleback biochemical responses as well as on fish population and community assemblages. Three sampling sites including Lézarde River (LEZ), Vallon du Vivier (VDV) and Val des Fontaines (VDF) were considered as having a low level of contamination by anthropogenic activities. The other four sites were considered as heavily contaminated by different activities. Among them, the stations located in the Réveillon River (REV) and the Rhonelle River (RHO) were selected because of their position within an urbanised and cultivated area. The Vilpion River station (VIL) was chosen because of its position within an intensive agricultural area, and the Escaut River station (ESC) because of its location within an heavily industrialised and urbanised area.

Table 1 
Since sticklebacks are able to inhabit in various hydrosystems, all investigated stations were characterised by position according to Huet's (1949) zonation and Strahler's (1957) rank determination (Table 1). Moreover, water temperature, $\mathrm{pH}$, dissolved oxygen concentration, conductivity and hardness were measured prior to fish sampling.

\subsection{Metal analysis in water}

In the beginning of the study, all water samples were analysed by ICP/AES (Inductively Coupled Plasma /Atomic Emission Spectrometry) according to the standard NF EN ISO 11885. These analyses were carried out in a semi-quantitative way (screening). A total of 33 inorganic elements were studied over a $0-10 \mathrm{mg} / \mathrm{L}$ concentration range. The limit of quantification, for all of them, was equal to $50 \mu \mathrm{g} / \mathrm{L}$. Subsequently to these results, the same samples were analysed by ICP/MS (Inductively Coupled Plasma / Mass Spectrometry) according to the standard NF EN ISO 17294. Samples were filtered (porosity $0.45 \mu \mathrm{m})$ prior to the analysis. Cadmium $(\mathrm{Cd})$, copper $(\mathrm{Cu})$, lead $(\mathrm{Pb})$ and zinc (Zn) were analysed quantitatively on the dissolved fraction. The concentration range was between 0 and $50 \mu \mathrm{g} / \mathrm{L}$. The limit of quantification was equal to $1 \mu \mathrm{g} / \mathrm{L}$ except for Cd that was equal to $0.09 \mu \mathrm{g} / \mathrm{L}$.

\subsection{Fish collection and tissue sampling}

Three-spined sticklebacks were collected during autumn 2005, between $16^{\text {th }}$ September and $5^{\text {th }}$ October, by electrofishing according to the standards "Sampling of fish with electricity" (EN 14011). The station of REV, LEZ, RHO, VIL and VDV were sampled by total prospecting with recall. For ESC and VDF, a number of sub-samples proportional to the diversity of the habitats present and representative in terms of richness, specific composition and abundance was sampled. Fish ranging from 35 to $60 \mathrm{~mm}$ in length were selected to measure biochemical parameters. A quota of 30 fish was chosen except 
at VDV and VDF where only 24 fish were sampled. In REV site, many sticklebacks exhibited external parasites and only fish without parasite infestation were used in the present study. After capture, the fish were weighed, measured and immediately sacrificed. Blood was collected, diluted 4-fold in phosphate buffer (100 mM, pH 7.8) and stored in liquid nitrogen prior VTG analysis. Liver, gonad, kidney and muscle were rapidly dissected, weighed and frozen in liquid nitrogen prior to homogenisation and biochemical analysis.

For all fish, the condition factor (CF) was calculated according to Pottinger et al. (2002), while somatic indexes for liver and gonad (HSI and GSI respectively) were calculated as (organ weight / fish weight).100.

\subsection{Biochemical analysis}

Livers were homogenised in ice-cold phosphate buffer (100 mM, pH 7.8) with $20 \%$ glycerol and $0.2 \mathrm{mM}$ phenylmethylsulfonyl fluoride as a serine protease inhibitor. The homogenates were centrifuged at $10,000 \mathrm{~g}, 4^{\circ} \mathrm{C}$, for $15 \mathrm{~min}$ and the post-mitochondrial fractions were used for biochemical assays. Total protein concentrations were determined using the method of Bradford (1976) with bovine serum albumin (SigmaAldrich Chemicals, France) as a standard. Hepatic biomarker assays including EROD, GST, GPx, GSH and TBARS were conducted, respectively, according to the methods of Flammarion et al. (1998a), Habig et al. (1974), Paglia and Valentine (1967), Vandeputte et al. (1994) and Ohkawa et al. (1979) adapted in microplate and optimised for stickleback as previously described (Sanchez et al., 2007).

As in the liver, all muscle samples were homogenised, centrifuged to obtain the postmitochondrial fraction and total protein concentrations were determined. AChE activity was measured in muscle according the method developed by Sturm et al. (2000). 
Butyril-cholinesterase was inhibited using tetraisopropyl pyrophosphoramide and the formation of 5-thio-2-nitro-benzoic acid generated by the sample diluted at $0.5 \mathrm{~g}$ of proteins/L or standard of AChE from electric eel (Sigma-Aldrich Chemicals) was monitored at $405 \mathrm{~nm}$. The results were expressed as $\mathrm{nmol} / \mathrm{min} / \mathrm{mg}$ of proteins. VTG concentration was measured in total blood according the method of Sanchez et al (2005). This assay is based on a competition for the anti-VTG antibodies (GA-306, Biosense Laboratories, Bergen, Norway) diluted to 1:1,000 between standard-VTG coated on the wells of a microtiter plate at $25 \mathrm{ng} / \mathrm{mL}$ and free VTG in the sample or standard solutions.

Spiggin was quantified in kidney. For this, $200 \mu \mathrm{L}$ of a strong denaturing buffer [100 $\mathrm{mM}$ Tris- $\mathrm{HCl}, 10 \mathrm{mM}$ EDTA, $8 \mathrm{M}$ urea, 2\% SDS (w/v), and $200 \mathrm{mM} \beta-$ mercaptoethanol; $\mathrm{pH} 8.5$ ] were added to kidney and samples were heated at $70^{\circ} \mathrm{C}$ for 30 min. The enzyme-linked immunosorbent assay (ELISA) procedure for spiggin has been described in detail elsewhere (Katsiadaki et al., 2002b). This assay is based on a competition for the anti-spiggin antibodies between protein derived from nests coated on the wells of a microtiter plate and free spiggin in the sample. Spiggin contents were expressed as units/kidney.

\subsection{Fish community assessment}

Disturbances of fish assemblage were assessed according to a Fish-Based Index (FBI) adapted to French ichthyofauna (Oberdorff et al., 2002). Several aspects of fish species composition, richness and abundance were evaluated through seven metrics including, number of total fish species, number of rheophile fish species, and number of litophile fish species, density of tolerant individuals, density of invertivore individuals, density of omnivore individuals and total density of fish assemblage. Environmental factors of 
sampling location such as sampling and watershed area, altitude, position in longitudinal gradient, were also included in the multimetric index calculation. The quality ratings were established as followed : High < 7; Good, ]7-16]; Moderate, ]1625]; Poor, ]25-36]; Bad, > 36 whilst 16 represented the optimal cut-off level for assemblage impairment.

\subsection{Statistical analysis}

The condition factor, somatic index and biomarker data are reported as mean \pm standard deviation and the SPSS 14.0 software was used for statistical analysis. Firstly, normal distribution and homoscedasticity of data were verified using Kolmogorov-Smirnov and Levene tests respectively. Since data sets did not have a normal distribution and/or homogeny of variance, the data was $\log$-transformed, using $\mathrm{F}(\mathrm{x})=\log (1+\mathrm{x})$, prior to parametric analysis. Secondly, a two-way analysis of variance (ANOVA) was performed for each parameter using sites and gender as factors. When sites by gender interaction was significant ( $\alpha=0.05)$, male and female data were treated separately. However, male and female GSI data were treated separately due to physiological differences between both genders. To determine the differences between biomarker responses measured in sampled sites, a one-way ANOVA followed by Sidak test $(\alpha=0.05)$ was performed.

\section{Results}

\subsection{Water quality}

Physicochemical data were interpreted according to the rules for Water Quality Index determination. These analyses did not provide an exhaustive view of water contamination but they did give some information on the water quality. Table 2 shows physicochemical parameters recorded in each sampled sites. The $\mathrm{pH}$ was stable and 
around neutral at all locations. The water at REV, ESC and RHO, three sites characterised by urban dense pressure, exhibited an high conductivity. Among these sites, REV was also characterised by a low dissolved oxygen concentration and an high temperature, results that point out the heavy contamination levels of this stream.

Table 2

Table 3 presents the metal concentrations measured in the studied sites. In LEZ, VDV and VDF surface water, no high metal concentration was detected. Conversely, all other streams were contaminated by several metals. High phosphorus concentrations were measured at REV, RHO, and ESC. Moreover, REV exhibited high copper and zinc concentrations and RHO was characterised by a heavily cadmium contamination. In ESC surface water, elevated concentrations of various metals such as aluminium, copper, iron, lead and zinc, were noticed. The site of VIL was characterised by high concentrations of copper and rubidium.

Table 3

\subsection{Biochemical biomarkers}

Results of biomarker measurements are presented in table 4. Biomarker responses did not appear as gender-dependent except for GPx that was characterised by a mean activity in females significantly more elevated than in males $(\mathrm{p}<0.05)$. The responses observed in various sampling locations were compared to data recorded at VDV that can be considered as an uncontaminated site.

Fish from REV and ESC exhibited an EROD activity of 30.06 $\pm 21.0 \mathrm{pmol} / \mathrm{min} / \mathrm{mg}$ and $31.3 \pm 17.6 \mathrm{pmol} / \mathrm{min} / \mathrm{mg}$ respectively that appeared as clearly elevated $(\mathrm{p}<0.05)$ compared to VDV $(7.2 \pm 6.3 \mathrm{pmol} / \mathrm{min} / \mathrm{mg})$. An increasing trend was also noticed in fish from LEZ and VDF. A decrease of EROD activity was noticed in fish from VIL that exhibited an EROD activity of $2.1 \pm 3.2 \mathrm{pmol} / \mathrm{min} / \mathrm{mg}$. GST activity measured in fish from REV (i.e. $3197 \pm 890 \mathrm{U} / \mathrm{g}$ ) appeared as strongly induced ( $\mathrm{p}<0.05)$ compared to all 
other sampling sites. Conversely, fish collected at VDV exhibited a significantly low value of $1024 \pm 167 \mathrm{U} / \mathrm{g}(\mathrm{p}<0.05)$ compared to other locations where GST activity ranged from $1386 \pm 256 \mathrm{U} / \mathrm{g}$ to $1662 \pm 278 \mathrm{U} / \mathrm{g}$.

The measurement of oxidative stress biomarkers showed that antioxidant defences were disturbed in fish from the most contaminated sites. GPx activity was strongly induced in both male and female fish from RHO and VIL $(\mathrm{p}<0.05)$. Fish from RHO and ESC were also characterised by a significant depletion of GSH with levels of $10.9 \pm 7.7 \mu \mathrm{mol} / \mathrm{g}$ and $7.0 \pm 4.8 \mu \mathrm{mol} / \mathrm{g}$ respectively. Conversely, GSH concentration was significantly increased in REV's fish $(40.2 \pm 16.0 \mu \mathrm{mol} / \mathrm{g} ; \mathrm{p}<0.05)$. Disturbances of antioxidant defences were associated to oxidative damage as lipoperoxidation in stickleback collected at REV, ESC and RHO that showed a TBARS concentrations significantly increased compared to VDV $(\mathrm{p}<0.05)$.

AChE activity was clearly affected in various investigated stations. This enzyme was inhibited in fish sampled at REV, ESC, RHO and VIL with values ranged from $67 \pm 11$ $\mathrm{nmol} / \mathrm{min} / \mathrm{mg}$ to $32 \pm 9 \mathrm{nmol} / \mathrm{min} / \mathrm{mg}$ but only sticklebacks from REV and VIL exhibited an inhibition factor below 50\%. Conversely, fish collected at VDF showed a weakly induction of AChE activity with a value of $102 \pm 18 \mathrm{nmol} / \mathrm{min} / \mathrm{mg}$. In this study, AChE activity was length-dependent $\left(\mathrm{AChE}=-82.748 \mathrm{Ln}(\right.$ length $)+379.57 ; \mathrm{R}^{2}=0.2166$; $\mathrm{p}<0.05)$. However, after data normalisation by fish length according the method described by Flammarion et al. (2002a), no significant difference between original and normalised data was noticed and, the effect of fish length has been ignored (data not shown).

The assessment of endocrine disruption biomarkers showed that fish from various sampling locations were probably exposed to estrogenic and/or androgenic compounds. 
Male sticklebacks from REV exhibited an induced VTG with a concentration of $21.8 \pm 17.2 \mu \mathrm{g} / \mathrm{mL}(\mathrm{p}<0.05)$. VTG was also significantly induced $(\mathrm{p}<0.05)$ in male fish collected at ESC and RHO with concentrations of $213.4 \pm 212.7 \mu \mathrm{g} / \mathrm{mL}$ and $70.3 \pm 39.1$ $\mu \mathrm{g} / \mathrm{mL}$ respectively. In these two sites, female sticklebacks showed also a significant SPG induction $(\mathrm{p}<0.05)$ with concentrations of $159.7 \pm 57.9 \mathrm{U} /$ kidney and $111.2 \pm 129.2$ U/kidney respectively.

\subsection{Somatic indexes and condition factor}

HSI, GSI and CF of stickleback from the different locations are shown in table 5. As for biochemical biomarkers, somatic index and condition factor variations were compared to data from VDV that can be considered as a reference site. No gender effect was recorded for these parameters. However, male and female GSI data were treated separately in light to physiological differences between both genders. HSI calculated for fish from REV, ESC, RHO and VIL were higher compared to other locations but, fish sampled at REV and RHO showed a strong increase of this index. GSI measured in fish from REV and VIL appeared as increased compared to VDV. Conversely, fish collected at LEZ exhibited a low value of GSI. CF was increased in fish from ESC, RHO and VIL. No significant difference was recorded in other investigated sites (i.e. REV, LEZ and VDF).

\subsection{Fish community assessment}

FBI calculated at each studied sites and associated fish species strength were presented in table 6. VDV, LEZ, and VIL had a weakly disturbed fish assemblage (i.e. FBI class $=1$ or 2) characterised by the presence of sensitive fish species such as eel (Anguilla anguilla), trout (Salmo trutta fario), Miller's thumb (Cottus gobio) and three-spined stickleback. Fish assemblage observed at ESC, RHO and VDF appeared as moderately disturbed (i.e. FBI class = 3) with a few sensitive fish species associated to a dominance 
of resistant species including roach (Rutilus rutilus) and nine-spined stickleback (Pungitius pungitius). REV exhibited a very strongly disturbed fish assemblage (i.e. FBI class $=5$ ) with a lack of typical fish species such as the Miller's thumb and the Eurasian minnow (Phoxinus phoxinus) and abundance of introduced fish such as the roach and the crucian carp (Carassius carassius).

\section{Discussion}

The present study aimed to determine the usefulness of a set of biomarkers, representing different biological functions in the stickleback, as an early warning system of freshwater contamination. We showed that biochemical biomarkers including biotransformation enzymes (EROD and GST), oxidative stress parameters (GPx, GSH and TBARS), neurotoxicity (AChE) and endocrine disruption indicators (VTG and SPG) showed various response profiles in different streams. For a better site characterisation based on chemical and biological information, these biochemical responses were compared to other end-points classically employed for environmental monitoring such as physico-chemical measurements and fish community assessment, or morphological indexes that are general indicator of fish health.

\subsection{Reduction of confounding factor influence}

Many studies reported the influence of various biotic and environmental factors such as age, gender, sampling season and feeding behaviour, on biomarker responses measured in aquatic organisms. In a preliminary investigation of multi-biomarker responses in stickleback sampled in contaminated streams, biotransformation activities, antioxidant defences and morphological indexes appeared as gender-dependent parameters. Moreover, some biomarkers exhibited a seasonal variability as reported for GST that showed higher levels in Autumn than in Spring (Sanchez et al., 2007). AChE activity 
has been extensively studied in stickleback (Sturm et al., 1999; Wogram et al., 2001) and, as reported for other fish species, this enzymatic activity is significantly associated with fish length and weight (Sturm et al., 1999). Hence, these confounding factors can prevent the use of biomarkers for routine environmental monitoring. However, there are many ways that allow reducing variability for a better application of biomarkers in a biomonitoring context. (1) Part of biomarker variability can be explained by the sampling regime itself. This could be reduced by an optimisation of sampling conditions (i.e. sampling during a short period, reduction of fish length range, increase of fish number)(Payne et al., 1996). (2) A better characterisation of confounding factors such as physico-chemical parameters in water and reproductive status of fish, could allow to explain the observed variability and to discriminate responses induced by pollutant exposure and background noise using appropriate statistical analysis (Sturm et al., 1999). (3) Data normalisation could also allow reducing biomarker variability as previously reported for gender differences in EROD activity (Flammarion et al., 1998a). In this work, sampling conditions were optimised to limit the variability due to sampling. For this purpose, fish with a length between 35 and $60 \mathrm{~mm}$, were collected during a four-week period out of their reproductive phase. Hence, compared to the preliminary investigation performed in sticklebacks sampled in Spring and in Autumn, the biomarker responses in the present study were characterised by a lack of gender difference according to the results previously reported in gudgeon (Faller et al., 2003; Flammarion and Garric, 1997). Moreover, the weight of fish length on AChE activity variations is strongly reduced and length can be ignored for data analysis as indicated in previous study (Payne et al., 1996).

\subsection{Selection of reference site}


The need of a reference site for qualitative and quantitative interpretation of wild fish biomarker responses has been reported by several field studies (Balk et al., 1996; Flammarion and Garric, 1997). Conversely to a previous investigation that used uncontaminated outdoor lotic mesocosms as reference (Sanchez et al., 2007), in the present work, we attempted to define a natural site as a true reference. An a priori approach pointed out three sites (LEZ, VDV and VDF) as candidate of reference status. All the sites were located in the upper area of the streams that were considered as suffering from a mixed environmental pressure (EEA, 2001). Physico-chemical analysis confirmed the lack of important contamination in these stations that exhibited high dissolved oxygen concentration and low conductivity (Table 2). The same conclusion was reached by metal analysis of surface waters, which showed very low or not detectable concentrations of major heavy metals (Table 3). Biomarker response profiles observed in these three sites also exhibited few significant differences, confirming further the low impact level at these locations. More specifically, the biomarker responses showed that fish collected in these three sites were probably not exposed to oxidative stress inducers or endocrine disrupter compounds. Indeed, the values measured in the present work for GPx, GSH and TBARS but also for VTG and SPG levels were consistent with the data reported in sticklebacks collected in uncontaminated outdoor mesocosms (Sanchez et al., 2007) and with the SPG concentrations reported in negative fish caged for three weeks in estuary (Allen et al., 2002). However, one of the investigated biomarkers, the AChE activity showed a significant increase in fish from VDF compared to other sites. This variation was below the range of $20 \%$ that is recognised as indicative of exposure to neurotoxic compounds (Payne et al., 1996) and could be related to natural variability of this enzyme. The 
recorded EROD activity showed also interesting trends. Indeed, the activities for LEZ and VDF were not in accordance with the basal levels reported in a previous field study (Sanchez et al., 2007) and could be considered as weakly induced. This finding was supported by close proximity of the site to an urbanised area and road infrastructures. In line with the in vivo responses, in vitro bioassay using PLHC-1 cell line indicated that sediments from LEZ were contaminated by aryl hydrocarbon receptor agonists (own unpublished data). According to these observations, VDV was selected as reference site to discuss biomarker responses in relation to other more impacted sites. This choice was also supported by the fish responses obtained from VDV, since the general indicators of fish health such as HSI, GSI and CF exhibited values in accordance with reference level reported in sticklebacks before in the scientific literature (Pottinger et al., 2002; Sanchez et al., 2007; Sokolowska et al., 2004).

\subsection{Individual effects in contaminated sites}

The usefulness of a set of biochemical biomarkers for aquatic biomonitoring have been reported by several studies (Galloway et al., 2004; Sanchez et al., 2007; Triebskorn et al., 2001). This biological tool provides valuable information in terms of knowledge of exposure to or effects of pollutants in organisms, and places into prospective the data on media contamination and environmental pressures, leading to a better characterisation of aquatic ecosystem quality. In our work, a noteworthy fact was that the biomarker responses patterns noticed in streams under to urban pressure (i.e. REV, ESC and RHO), showed many similarities suggesting that sticklebacks collected in these sites underwent similar sublethal stresses. In all of these sites, the estrogen-dependent yolk precursor VTG was detected in the blood of male sticklebacks. The abnormal synthesis of this protein reflected fish exposure to estrogenic compounds. This result is in accordance 
with several studies that reported surface water contamination by xenoestrogens such as 17 $\alpha$-ethinylestradiol, estrone, $17 \beta$-estradiol but also 4-nonylphenol and bisphenol A. The presence of xenoestrogens is usually linked with water bodies that receive mainly domestic wastewater from sewage treatment works and where VTG induction in collected male fish is evident (Parkkonen et al., 2000; Vethaak et al., 2005). In the same sites, fish were probably exposed to various pollutants able to generate neurotoxic effects and oxidative stress as indicated by AChE inhibition and TBARS increase respectively. Historically, $\mathrm{AChE}$ has been described as a biomarker of exposure to organophosphates and carbamates, but several laboratory studies showed that this enzyme can be inhibited by other contaminants such as dioxin-like compounds (Payne et al., 1996). Many of these contaminants are also described as inducers of lipoperoxidation (i.e. TBARS), a parameter described as one of the best biomarkers for biomonitoring, since it reveals oxidative stress-induced damages and not only exposure to pollutants (Van der Oost et al., 2003). In our study, other investigated biomarkers showed different response profiles between sites, consistent with data previously reported for these locations (Sanchez et al., 2007), and which allowed to distinguish the urban contaminated sites. Briefly, responses of GPx and GSH confirmed that sticklebacks were submitted to oxidative stress. GPx was strongly induced at RHO but also at VIL. Similar levels of induction have not been described in the scientific literature before and could reflect the exposure to complex mixtures in the field. Moreover, GSH was depleted in fish from ESC and RHO, two sites characterised by heavy metal contamination. This result is in accordance with the known mode of action of metals reported by laboratory experiments (Sanchez et al., 2005). EROD activity, a recognized biomarker of exposure to dioxin-like compounds (Van der Oost et al., 2003), 
was also induced in two sites (REV and ESC) located in watershed with high rates of urbanisation and industrialisation, activities recognised to released dioxin-like compounds in the environment. Moreover, to our knowledge, this study is the first field experiment that reports the induction of androgen-dependent protein SPG in wild stickleback populations. The increases of spiggin content in fish from ESC and RHO suggested that these fish were exposed to androgenic compounds. Surface water contamination by this class of endocrine disrupters is very little documented (Blankvoort et al., 2005; Soto et al., 2004) with the exception of pulp mill effluents that have an well-known masculinising effect (Cody and Bortone, 1997; Denton et al., 1985; Howell and Denton, 1989). Recently, Blankvoort et al. (2005) reported contamination of European rivers by many androgens including testosterone and its metabolites, $17 \alpha-$ methyltestosterone or trenbolone, that were probably released in aquatic ecosystems by sewage treatment plants and industrial activities, and that could induce spiggin in female sticklebacks.

The biomarker response profile in VIL, a stream subject to an intensive agricultural pressure, appeared as very different compared to the other contaminated sites. Fish were characterised by a strong inhibition of AChE activity combined with an induction of antioxidant defences without lipoperoxidation phenomenon and a decrease of EROD activity. These responses are consistent with the known mode of action of heavy metals, which were not implicated in the alleged profile of VIL's contamination, and pesticides which are extensively used in the VIL watershed area that is released into aquatic ecosystems (Direction de l'Environement Picardie, unpublished data). Among these pesticides, many substances are known to inhibit AChE activity (Bretaud et al., 2000; Wogram et al., 2001) and/or induce oxidative stress (Kavitha and Venkateswara Rao, 
2007) in aquatic organisms whilst organophosphate are also known as catalytic inhibitors of EROD activity (Flammarion et al., 1998b).

The organo-somatic indexes and $\mathrm{CF}$ are integrative indicators that provide valuable information on fish health and reproductive status. These parameters are widely used for freshwater biomonitoring. However, they are considered as weak discriminators since their responses are influenced by factors other than chemical contamination such as food availability, parasitism and disease. In the contaminated sites investigated here, one or more of these morphological parameters were increased compared to reference site and the basal levels previously described for this species (Pottinger et al., 2002; Sanchez et al., 2007; Sokolowska et al., 2004). Hence, the variations observed for these general indicators could be cautiously linked to biochemical responses. For example, the HSI increase observed, could be linked to implication of liver in VTG synthesis at REV, ESC and RHO and/or to the role of this organ in detoxification process. In a same manner, GSI could be increased follow the exposure to contaminant able to disturb reproductive cycle as previously reported in fish exposed to a variety of endocrinemodulating substances (Orlando et al., 2004). For example, estrogens could be implicated at REV where VTG was induced, however, but other compounds could explain the increase in GSI noticed at VIL where endocrine disruption biomarker were not present. The high CF noticed at ESC, RHO and VIL showed that fish health status was variable between the contaminated streams investigated here. However, $\mathrm{CF}$ is a very sensitive parameter responding to biotic and abiotic factors hence, no clear relationship was allowed between chemical contamination and $\mathrm{CF}$ variations.

\subsection{Relationship between biochemical endpoint and community assessment}


Fish community is considered as a valuable endpoint for integrative stream monitoring because of their position at the top of the trophic food web (Siligato and Bohmer, 2002; Smith et al., 1999). Hence, several biotic indexes based on fish community assessment have been developed and validated for specific geographical application (Karr, 1981; Kestemont et al., 2000; Oberdorff et al., 2002). In this study, we used the Fish Based Index (FBI) developed by Oberdorff et al. (2002) and adapted to French ichthyofauna, to evaluate fish community disturbances in sampling sites. Among weakly contaminated streams where fish were characterised by low responses to biomarkers, two of them (i.e. LEZ and VDV) exhibited an undisturbed fish assemblage characterised by the presence and abundance of sensitive species (Table 6). Conversely, REV, ESC and RHO sites, that were subjects to various contamination sources and where sticklebacks were clearly affected by water pollution, exhibited moderate to high disturbances of fish assemblage (Table 6). The low quality of fish assemblage in both sites could be explained by water quality alteration but other factors such as habitat modifications or fish species introduction. In both previously described locations, all investigated parameters converged towards the same conclusion indicating the high or the low quality of aquatic ecosystems. In other sites, the conclusions provided by chemical, biochemical and biological indicators differed on certain points. Indeed, VDF fish assemblage was moderately disturbed but this site exhibited good water quality and sticklebacks with low response levels of biomarkers. These observations reflected the lack of perfect relationship between parameters indicating disturbances at various biological organisation levels. Moreover, they confirmed the dependence of biotic index to degradation of the natural habitat by factors other than chemical contamination, such as high predation intensity, fish pathologies or habitat structure modifications (Fischnetz, 
2004; Siligato and Bohmer, 2002; Smith et al., 1999). Conversely to VDF, VIL was characterized by a very degraded water quality and fish exhibiting strong biomarker responses even though fish community was weakly impacted. This result shows also the lack of relationship between biochemical endpoints and population measurements as reported for several other biomarkers (Kloepper-Sams et al., 1994; Roy et al., 2003) and argued for a freshwater monitoring based on multiparametric approach.

\section{Conclusion}

Several studies have promoted the stickleback as a valuable sentinel for aquatic ecosystem biomonitoring. The present work provided new evidence in favour of the use of the stickleback for this purpose. Indeed, SPG have been extensively used in laboratory to characterise (anti)-androgenicity of chemicals. We showed here that SPG measurement in wild sticklebacks provided evidence to exposure to androgenic contaminants in the environment. In this context, the stickleback appears as an interesting sentinel fish species that can provide additional information on the chemical contamination of ecosystems compared to other species traditionally used for environmental biomonitoring such as chub and roach. The other investigated biomarkers showed various response patterns consistent with environmental pressures and chemical contamination in sampling sites. These biochemical responses provided site-specific profiles that highlighted contamination data and allowed to distinguish sampling locations. However, biomarker responses are little informative to disturbances at higher levels of organisation. Hence, in this study, we assessed fish community parameters that reflect integrated conditions over a long time period and are more ecologically relevant. We reported population disturbances in several sampling sites, induced by chemical contamination and/or other various factors, but we also noticed a 
lack of clear relationship between biomarker variations and population responses. Also, this study argued for a multi-parametric approach of aquatic ecosystem contamination based on association between chemical, biochemical and population endpoints. As observed in the present field study, this kind of experiment generates large data sets making their interpretation by environmental managers in order to evaluate freshwater quality an onerous task. Hence, further studies are needed and are in progress to with the aim of developing and validating a specific ecological indicator that allows stream classification based on biomarker responses.

\section{Acknowledgements}

We thank the official fishguards from the "Office National de l'Eau et des Milieux Aquatiques" for the technical assistance in fish sampling. We thank also K. Tack and L. Meunier from environmental chemistry unit of INERIS for metal analysis in surface water. This work was supported by the French Ministry of Ecology and Sustainable Development (Budget Civil de la Recherche et du Développement AP-2004) and the "région Picardie".

Ethical considerations : The procedures described in the present paper are conducted in accordance with the laws and regulations controlling experiments with life animals in France. All experimental protocols were approved by the Ethical Committee of the French National Institute of Industrial Environment and Risks.

\section{References}

Allen, Y.; Balaam, J.; Bamber, S.; Bates, H.; Best, G.; Begnell, J.; Brown, E.; Craft, J.; Davies, J.M.; Depledge, M.H.; Dyer, R.A.; Feist, S.; Hurst, M.R.; Hutchinson, T.H.; Jones, G.; Jones, M.B.; Katsiadaki, I.; Kirby, M.F.; Leah, R.; Matthiessen, P.;, Megginson, C.; Moffat, C.F.; Moore, A.; Pirie, D.; Robertson, F.; Robinson, C.D.; 
Scott, A.P.; Simpson, M.G.; Smith, A.; Stagg, R.M.; Struthers, S.; Thain, J.E.; Thomas, K.V.; Tolhurst, L.; Waldock, M.J.; Walker, P. Final report : Endocrine Disruption in the Marine Environment (EDMAR); 2002.

Amiard, J.C.; Caquet, T.; Lagadic, L. Les biomarqueurs parmi les méthodes d'évaluation de la qualité de l'environnement. In: Lagadic, L.; Caquet, T.; Amiard, J.C.; Ramade, F. (Eds.), Utilisation de biomarqueurs pour la surveillance de la qualité de l'environnement. Lavoisier, Londres, Paris, New York, pp. XXI-XXXI; 1998.

Balk, L.; Larsson, A.; Forlin, L. Baseline studies of biomarkers in the feral female perch (Perca fluviatilis) as tools in biological monitoring of anthropogenic substances. Mar. Environ Res. 42: 203-208; 1996.

Blankvoort, B.M.G.; Rodenburg, R.J.T.; Murk, A.J.; Koeman, J.H.; Schilt, R.; Aarts, J.M.M.J.G. Androgenic activity in surface water samples detected using the AR-LUX assay: indications for mixture effects. Environ Toxicol Pharmacol. 19: 263-272; 2005. Bradford, M.M. A rapid sensitive method for the quantitation of microgram quantities of protein utilizing the principle of protein-dye binding. Anal Biochem. 72: 248-254; 1976.

Bretaud, S.; Toutant, J.-P.; Saglio, P. Effects of carbofuran, diuron, and nicosulfuron on acetylcholinesterase activity in goldfish (Carassius auratus). Ecotoxicol Environ Saf. 47: 117-124; 2000.

Carle, F.L.; Strub, M.R. A new method for estimating population size from renoval data. Biometrics. 34: 621-630; 1978.

Cody, R.P.; Bortone, S.A. Masculinization of mosquitofish as an indicator of exposure to kraft mill effluent. Bull Environ Contam Toxicol. 58: 429-436;. 1997. 
Denton, T.E.; Howell, W.M.; McCollum, C.J.; Marks, E.B.; Allison, J.J. Masculinization of female mosquitofish by exposure to plant sterols and Mycobacterium smegmatis. Bull Environ Contam Toxicol. 35: 627-632; 1985. EEA (European Environmental Agency). Reporting river quality using the Water Quality Accounts methodology. Application within the Eurowaternet process, Copenhagen; 2001.

Faller, P.; Kobler, B.; Peter, A.; Sumpter, J.P.; Burkhardt-Holm, P. Stress status of gudgeon (Gobio gobio) from rivers in switzerland with and without input of sewage treatment plant effluent. Environ Toxicol Chem. 22: 2063-2072; 2003.

Fischnetz. Sur la trace du déclin piscicole. Rapport final. Dübendorf, Bern : EAWAG/OFEFP; 2004.

Flammarion, P.; Garric, J. Cyprinids EROD activities in low contaminated rivers: a relevant statistical approach to estimate reference levels for EROD biomarker? Chemosphere. 35: 2375-2388; 1997.

Flammarion, P.; Migeon, B.; Garric, J. Statistical analysis of cyprinid ethoxyresorufinO-deethylase data in a large french watershed. Ecotoxicol Environ Saf. 40: 144-153; 1998a.

Flammarion, P.; Noury, P.; Garric, J. The measurement of cholinesterase activities as a biomarker in chub (Leuciscus cephalus): the fish length should not be ignored. Environ Poll. 120: 325-330; 2002a.

Flammarion, P.; Migeon, B.,; Urios, S.; Morfin, P.; Garric, J. Effect of methidathion on the cytochrome P-450 1A in the cyprinid fish gudgeon (Gobio gobio). Aquat Toxicol. 42: 93-102; 1998b. 
Flammarion, P.; Devaux, A.; Nehls, S.; Migeon, B.; Noury, P.; Garric, J.

Multibiomarker responses in fish from the Moselle river (France). Ecotoxicol Environ Saf. 51: 145-153; $2002 b$.

Galloway, T.S.; Brown, R.J.; Browne, M.A.; Dissanayake, A.; Lowe, D.; Jones, M.B.; Depledge, M.H. A multibiomarker approach to environmental assessment. Environ Sci Technol. 38: 1723-1731; 2004.

Habig, W.H.; Pabst, M.J.; Jakoby, W.B. Glutathione S-Transferases. The first enzymatic step in mercapturic acid formation. J Biol Chem. 249: 7130-7139;1974. Handy, R.D.; Runnalls, T.; Russel, P.M. Histopathologic biomarkers in three spined sticklebacks, Gasterosteus aculeatus, from several rivers in Southern England that meet the freshwater fisheries directive. Ecotoxicology. 11: 467-479; 2002.

Holm, G.; Lundström, J.; Andersson, T.; Norrgren, L. Influences of halogenated organic substances on ovarian development and hepatic EROD activity in the thrre-spined stickleback, Gasterosteus aculeatus, and rainbow trout, Oncorhynchus mykiss. Aquat Toxicol. 29: 241-256; 1994.

Howell, W.M.; Denton, T.E. Gonopodial morphogenesis in female mosquitofish, Gambusia affinis affinis, masculinized by exposure to degradation products from plant sterols. Environ Biol Fish. 24: 43-51; 1989.

Huet, M. Aperçu des relations entre la pente et les populations piscicoles des eaux courantes. Schweiz Z Hydrol. I1: 332-351; 1949.

Jakobsson, S.; Borg, B.; Haux, C.; Hyllner, S.J. An 11-ketotestosterone induced kidneysecreted protein: the nest building glue from male three-spined stickleback, Gasterosteus aculeatus. Fish Physiol Biochem. 20: 79-85; 1999. 
Karr, J.R. Assessment of biotic integrity using fish communities. Fisheries. 6: 21-27; 1981.

Katsiadaki, I.; Scott, A.P.; Mayer, I. The potential of the three-spined stickleback (Gasterosteus aculeatus L.) as a combined biomarker for oestrogens and androgens in European waters. Mar Environ Res. 54: 725-728; 2002a.

Katsiadaki, I.; Scott, A.P.; Hurst, M.R.; Matthiessen, P.; Mayer, I. Detection of environmental androgens: a novel method based on enzyme-linked immunosorbent assay of spiggin, the stickleback (Gasterosteus aculeatus) glue protein. Environ Toxicol Chem 21: 1946-1954; $2002 b$.

Katsiadaki, I.; Morris, S.; Squires, C.; Hurst, M.R.; James, J.D.; Scott, A.P. A sensitive, in vivo test for the detection of environmental anti-androgens, using the three-spined stickleback (Gasterosteus aculeatus). Environ Health Persp. 114: 115-121; 2006. Kavitha, P.; Venkateswara Rao, J. Oxidative stress and locomotor behaviour response as biomarkers for assessing recovery status of mosquito fish, Gambusia affinis after lethal effect of an organophosphate pesticide, monocrotophos. Pest Biochem Physiol. 87: 182-188; 2007.

Kestemont, P.; Didier, J.; Depiereux, E.; Micha, J.-C. Selecting ichthyological metrics to assess river quality basin ecological quality. Arch Hydrobiol. Suppl. 121: 321-348; 2000.

Kloepper-Sams, P.M.; Swanson, S.M.; Marchant, T.; Schryer, R.; Owens, J.W. Exposure of fish to biologically treated bleached-kraft effluent. 1. Biochemical, physiological and pathological assessment of rocky montain whitefish (Prosopium williasoni) and longnose sucker (Catostomus catostomus). Environ Toxicol Chem. 13: 1469-1482; 1994. 
Lagadic, L.; Caquet, T.; Amiard, J.C., Biomarqueurs en écotoxicologie : principes et définitions. In: Lagadic, L.; Caquet, T.; Amiard, J.C.; Ramade, F. (Eds.), Biomarqueurs en écotoxicologie : aspects fondamentaux. Masson, Londres, Paris, New York; 1997. Oberdorff, T.; Pont, D.; Hugueny, B.; Belliard, J.; Berrebi Dit Thomas, R.; Porcher, J.P. Adaptation et validation d'un indice poisson (FBI) pour l'évaluation de la qualité biologique des cours d'eau français. Bull Fr Pêche Piscic. 365/366: 405-433; 2002. Ohkawa, H.; Ohishi, N.; Yagi, K. Assay for lipid peroxides in animal tissues by thiobarbituric acid reaction. Anal Biochem. 95: 351-358; 1979.

Orlando, E.F.; Kolok, A.S.; Binzcik, G.A.; Gates, J.L.; Horton, M.K.; Lambright, C.S. Endocrine-disrupting effects of cattle feedlot effluent on an aquatic sentinel species, the fathead minnow. Environ Health Persp. 112: 353-358; 2004.

Paglia, D.E.; Valentine, W.N. Studies on the quantitative and qualitative characterization of erythrocyte glutathione peroxidase. J Lab Clin Med. 70: 158-169; 1967.

Parkkonen, J.; Larsson, D.G.J.; Adolfsson-Erici, M.; Pettersson, M.; Berg, A.H.; Olsson, P.-E.; Forlin, L. Contraceptive pill residues in sewage effluent are estrogenic to fish. Mar Environ Res. 50: 198; 2000.

Payne, J.F.: Mathieu, A.: Melvin, W.: Fancey, L.L. Acetylcholinesterase, an old biomarker with a new future? Field trials in association with two urban rivers and a paper mill in Newfoundland. Mar Poll Bull. 32: 225-231; 1996.

Pottinger, T.G.; Carrick, T.R.; Yeomans, W.E. The three-spined stickleback as an environmental sentinel: effects of stressors on whole-body physiological indices. J Fish Biol. 61: 207-229; 2002. 
Prygiel, J. Management of the diatom monitoring networks in France in 2000. J Appl Phycol. 14: 19-26; 2002.

Prygiel, J.; Rosso-darmet, A.; Lafont, M.; Lesniak, C.; Durbec, A.; Ouddane, B. Use of Oligochaete communities for assessment of ecotoxicological risk in fine sediments of rivers and canals of the Artois-Picardie water basin (France). Hydrobiologia. 410: 2537; 1999.

Roy, L.; Armstrong, J.; Sakamoto, K.; Steinert, S.; Perkins, E.; Lomax, D.; Johnson, L.; Schlenk, D. The relationships of biochemical endpoints to histopathology and population metrics in feral flatfish species collected near the municipal wastewater outfall of Orange County, California, USA. Environ Toxicol Chem. 22: 1309-1317; 2003.

Sanchez, W.; Palluel, O.; Lagadic, L.; Aït-Alïssa, S.; Porcher, J.-M. Biochemical effects of nonylphenol polyethoxylate adjuvant, Diquat herbicide and their mixture on the three-spined stickleback (Gasterosteus aculeatus L.). Mar Environ Res. 62: S29-S33; 2006.

Sanchez, W.; Aït-Aïssa, S.; Palluel, O.; Ditche, J.M.; Porcher, J.M. Preliminary investigation of multi-biomarker responses in three-spined stickleback (Gasterosteus aculeatus L.) sampled in contaminated streams. Ecotoxicology. 16: 279-287; 2007. Sanchez, W.; Palluel, O.; Meunier, L.; Coquery, M.; Porcher, J.-M.; Aït-Aïssa, S. Copper-induced oxidative stress in three-spined stickleback: relationship with hepatic metal levels. Environ Toxicol Pharmacol. 19: 177-183; 2005.

Schmitt, C.J.; Ellen Hinck, J.; Blazer, V.S.; Denslow, N.D.; Dethloff, G.M.; Bartish, T.M.; Coyle, J.J.; Tillitt, D.E. Environmental contaminants and biomarker responses in 
fish from the Rio Grande and its U.S. tributaries: Spatial and temporal trends. Sci Total Environ. 350: 161-193; 2005.

Sebire, M.; Katsiadaki, I.; Scott, A.P. Non-invasive measurement of 11ketotestosterone, cortisol and androstenedione in male three-spined stickleback (Gasterosteus aculeatus). Gen Comp Endocrinol. 152: 30-38; 2007.

Siligato, S.; Bohmer, J. Evaluation of biological integrity of a small urban stream system by investigating longitudinal variability of the fish assemblage. Chemosphere. 47: 777-788; 2002.

Smith, A.K.; Ajani, P.A.; Roberts, D.E. Spatial and temporal variation in fish assemblages exposed to sewage and implications for management. Mar Environ Res. 47: 241-260; 1999.

Sokolowska, E.; Kalamarz, H.; Kulczykowska, E. Seasonal changes in brain melatonin concentration in the three-spined stickleback (Gasterosteus aculeatus): towards an endocrine calendar. Comp Biochem Physiol Part A. 139: 365-369; 2004.

Soto, A.M.; Calabro, J.M.; Prechtl, N.V.; Yau, A.Y.; Orlando, E.F.; Daxenberger, A.; Kolok, A.S.; Guillette, L.J., Jr.; le Bizec, B.; Lange, I.G.; Sonnenschein, C. Androgenic and estrogenic activity in water bodies receiving Cattle Feedlot effluent in Eastern Nebraska, USA. Environ Health Persp. 112: 346-352; 2004.

Strahler, A.N. Quantitative analysis of watershed geomorphology. Trans Am Geophys Union. 38: 913-920; 1957.

Sturm, A.; Wogram, J.; Hansen, P.D.; Liess, M. Potential use of cholinesterase in monitoring low levels of organophosphates in small streams: natural variability in threespined stickleback (Gasterosteus aculeatus) and relation to pollution. Environ Toxicol Chem. 18: 194-200; 1999. 
Sturm, A.; Wogram, J.; Segner, H.; Liess, M. Different sensitivity to organophosphates of acetylcholinesterase and butyrylcholinesterase from three-spined stickleback (Gasterosteus aculeatus): application in biomonitoring. Environ Toxicol Chem. 19: 1607-1615; 2000.

Triebskorn, R.; Böhmer, J.; Braunbeck, T.; Honnen, W.; Köhler, H.-R.; Lehmann, R.; Oberemm, A.; Schwaiger, J.; Segner, H.; Schüürmann, G.; Traunspurger, W. The project VALIMAR (VALIdation of bioMARkers for the assessment of small stream pollution): objectives, experimental design, summary of results, and recommendations for the application of biomarkers in risk assessment. J Aquat Ecosyst Stress Recovery. 8: 161-178; 2001.

Van der Oost, R.; Beyerb, J.; Vermeulen, N. Fish bioaccumulation and biomarkers in environmental risk assessment: a review. Environ Toxicol Pharmacol 13: 57-149; 2003. Vandeputte, C.; Guizon, I.; Genestie-Denis, I.; Vannier, B.; Lorenzon, G. A microtiter plate assay for total glutathione and glutathione disulfide contents in cultured/isolated cells: performance study of a new miniaturized protocol. Cell Biol Toxicol 10: 415-421; 1994.

Vethaak, A.D.; Lahr, J.; Schrap, S.M.; Belfroid, A.C.; Rijs, G.B.J.; Gerritsen, A.; de Boer, J.; Bulder, A.S.; Grinwis, G.C.M.; Kuiper, R.V. An integrated assessment of estrogenic contamination and biological effects in the aquatic environment of The Netherlands. Chemosphere. 59: 511-524; 2005.

Wasson, J.G.; Chandesris, A.; Pela, H.; Blanc, L. Les hydro-écorégions de France métropolitaine. Approche régionale de la typologie des eaux courantes et éléments pour la définition des peuplements de référence d'invertébrés. Ministère de l'Ecologie et du Développement Durable, Cemagref BEA/LHQ.; 2002. 
Wogram, J.; Sturm, A.; Segner, H.; Liess, M. Effects of parathion on acetylcholinesterase, butyrilcholinesterase and carboxylesterase in three-spined stickleback (Gasterosteus aculeatus) following short term exposure. Environ Toxicol Chem. 20: 1528-1531; 2001. 
Table 1. Summary of some general characteristics of the investigated sites

\begin{tabular}{|c|c|c|c|c|c|c|c|}
\hline Sites & $\begin{array}{l}\text { Réveillon } \\
\text { (REV) }\end{array}$ & $\begin{array}{l}\text { Lézarde } \\
\text { (LEZ) }\end{array}$ & $\begin{array}{l}\text { Escaut } \\
\text { (ESC) }\end{array}$ & $\begin{array}{c}\text { Rhonelle } \\
\text { (RHO) }\end{array}$ & $\begin{array}{l}\text { Vilpion } \\
\text { (VIL) }\end{array}$ & $\begin{array}{c}\text { Vallon du } \\
\text { Vivier } \\
\text { (VDV) } \\
\end{array}$ & $\begin{array}{c}\text { Val des } \\
\text { Fontaines } \\
\text { (VDF) }\end{array}$ \\
\hline \multirow[b]{2}{*}{ GPS coordinates } & $\mathrm{N} 48^{\circ} 43^{\prime} 00^{\prime \prime}$ & N 49³4’09” & N 5323'40” & N 50¹7’49” & N $49^{\circ} 43^{\prime} 23^{\prime \prime}$ & $\mathrm{N} 49^{\circ} 43^{\prime} 23^{\prime \prime}$ & ${\mathrm{N} 49^{\circ} 29^{\prime} 33^{\prime \prime}}^{\prime}$ \\
\hline & E 2॰32’09” & Е $0^{\circ} 13^{\prime} 20^{\prime \prime}$ & E 332’56”' & E $3^{\circ} 32^{\prime} 41^{\prime \prime}$ & E $3^{\circ} 42^{\prime} 45^{\prime \prime}$ & Е $0^{\circ} 27^{\prime} 42^{\prime \prime}$ & E $0^{\circ} 24^{\prime} 37^{\prime \prime}$ \\
\hline $\begin{array}{l}\text { Watershed area } \\
\left(\mathrm{km}^{2}\right)\end{array}$ & 145 & 62 & 1650 & 73 & 377 & 25 & 10 \\
\hline Strahler's rank ${ }^{1}$ & 2 & 1 & 4 & 2 & 3 & 1 & 1 \\
\hline Huet's zonation ${ }^{2}$ & Barbel & Trout & Bream & Barbel & Barbel & Trout & Trout \\
\hline Pressure $^{3}$ & Urban dense & Mixed & Urban dense & Urban dense & $\begin{array}{l}\text { Intensive } \\
\text { agriculture }\end{array}$ & Mixed & Mixed \\
\hline Water Quality ${ }^{4}$ & Very bad & Good & $\mathrm{Bad}$ & $\mathrm{Bad}$ & Very bad & Very good & n.d. \\
\hline
\end{tabular}

1. Strahler's rank based on structure and density of hydrographic network (Strahler, 1957).

2. Huet's zonation was determined according to (Huet, 1949).

3. Data obtained from the Eurowaternet database of European Environment Agency (EEA, 2001).

4. Data obtained from French water agencies. 
Table 2. Physico-chemical characterisation of water for both sampling locations.

\begin{tabular}{lccccccc}
\hline & REV & LEZ & ESC & RHO & VIL & VDV & VDF \\
\hline $\begin{array}{l}\text { Water } \\
\text { temperature }\left({ }^{\circ} \mathrm{C}\right)\end{array}$ & 17.6 & 14.3 & 14.7 & 11.4 & 13.4 & 11.5 & 12.4 \\
$\mathrm{pH}$ & 7.7 & 7.5 & 7.5 & 7.7 & 7.8 & 7.3 & 7.1 \\
$\begin{array}{l}\text { Dissolved oxygen } \\
(\mathrm{mg} / \mathrm{L})\end{array}$ & 6.1 & 11.3 & 8.6 & 10.6 & 10.1 & 10.7 & 9.1 \\
$\begin{array}{l}\text { Conductivity } \\
(\mu \mathrm{S} / \mathrm{cm})\end{array}$ & 812 & 627 & 854 & 804 & 600 & 487 & 565 \\
$\begin{array}{l}\text { Total hardness } \\
(\mathrm{mg} / \mathrm{L})\end{array}$ & 232 & 285 & 340 & 323 & 232 & 200 & 140 \\
\hline
\end{tabular}


Table 3. Water composition determined for 33 inorganic elements at both sampling locations.

Data are expressed as mg/L except for $\mathrm{Cd}, \mathrm{Cu}, \mathrm{Pb}$ and $\mathrm{Zn}$ where data are expressed as $\mu \mathrm{g} / \mathrm{L}$.

\begin{tabular}{|c|c|c|c|c|c|c|c|}
\hline & REV & LEZ & ESC & RHO & VIL & VDV & VDF \\
\hline $\mathrm{Al}$ & 0,19 & n.d. & 0,43 & 0,17 & 0,12 & n.d. & 0,06 \\
\hline B & n.d. & n.d. & 0,11 & 0,06 & n.d. & n.d. & n.d. \\
\hline $\mathrm{Ca}$ & 88 & 98 & 94 & 93 & 97 & 92 & 96 \\
\hline $\mathrm{Cd}(\mu \mathrm{g} / \mathrm{L})$ & n.d. & n.d. & 0,09 & 0,118 & n.d. & n.d. & n.d. \\
\hline $\mathrm{Cu}(\mu \mathrm{g} / \mathrm{L})$ & 4 & 1 & 6 & 2 & 3 & 1 & 1 \\
\hline $\mathrm{Fe}$ & 0,3 & 0,07 & 0,86 & 0,25 & 0,15 & n.d. & 0,06 \\
\hline $\mathrm{K}$ & 4,8 & 1,7 & 9,8 & 5,9 & 3,2 & 1,5 & 7,9 \\
\hline $\mathrm{Mg}$ & 5,1 & 3,7 & 9,5 & 10 & 2,8 & 2,3 & 2,6 \\
\hline Mn & 0,09 & n.d. & 0,06 & n.d. & n.d. & n.d. & n.d. \\
\hline $\mathrm{Na}$ & 20 & 17 & 36 & 22 & 9,5 & 12 & 18 \\
\hline $\mathrm{P}$ & 0,37 & 0,05 & 0,48 & 0,45 & 0,17 & n.d. & 0,26 \\
\hline $\mathrm{Pb}(\mu \mathrm{g} / \mathrm{L})$ & 3 & 1 & 12 & 1 & 1 & 1 & 1 \\
\hline $\mathrm{Rb}$ & 0,2 & n.d. & n.d. & 0,08 & 0,59 & 0,1 & n.d. \\
\hline S & 20 & 4,6 & 18 & 18 & 5,5 & 2 & 3,8 \\
\hline $\mathrm{Si}$ & 3,6 & 7,3 & 7,6 & 7,8 & 5 & 4,7 & 4,8 \\
\hline $\mathrm{Sr}$ & 1,3 & 0,78 & 2,1 & 1,5 & 0,94 & 0,46 & 0,46 \\
\hline $\mathrm{Zn}(\mu \mathrm{g} / \mathrm{L})$ & 15 & 2 & 42 & 11 & 10 & 1 & 5 \\
\hline
\end{tabular}


Table 4. Biomarker responses for three-spined stickleback caught at the different sampling sites. Data are reported as mean \pm standard deviation.

Values not sharing a common letter within a biomarker are statistically different from each other (ANOVA followed by Sidak test, $\mathrm{p}<0.05$ ).

\begin{tabular}{|c|c|c|c|c|c|c|c|c|c|c|}
\hline \multirow{2}{*}{ Sites } & \multirow{2}{*}{ Sex } & \multirow{2}{*}{ Number } & EROD & GST & GPx & GSH & TBARS & AChE & Vtg & Spg \\
\hline & & & $\mathrm{pmol} / \mathrm{min} / \mathrm{mg}$ & U/g prot. & U/g prot. & $\mu \mathrm{mol} / \mathrm{g}$ prot. & $\mathrm{nmol} / \mathrm{g}$ prot. & U/mg prot. & $\mu \mathrm{g} / \mathrm{L}$ & U/kidney \\
\hline \multirow{2}{*}{ REV } & $\mathrm{M}$ & 15 & \multirow{2}{*}{$30,6 \pm 21,0^{\mathrm{d}, \mathrm{e}}$} & \multirow{2}{*}{$3197 \pm 890^{c}$} & $67,2 \pm 45,9^{\mathrm{a}}$ & \multirow{2}{*}{$40,2 \pm 16,0^{c}$} & \multirow{2}{*}{$162 \pm 86^{\mathrm{d}}$} & \multirow{2}{*}{$41 \pm 11^{\mathrm{a}, \mathrm{b}}$} & $21,8 \pm 17,2$ & - \\
\hline & $\mathrm{F}$ & 15 & & & $77,7 \pm 46,3^{\mathrm{a}}$ & & & & - & $76,5 \pm 25,8^{\mathrm{a}, \mathrm{b}, \mathrm{c}}$ \\
\hline \multirow{2}{*}{ LEZ } & $\mathrm{M}$ & 12 & \multirow{2}{*}{$13,0 \pm 8,8^{c, d}$} & \multirow{2}{*}{$1662 \pm 278^{b}$} & $83,2 \pm 34,1^{a}$ & \multirow{2}{*}{$26,1 \pm 11,1^{b, c}$} & \multirow{2}{*}{$54 \pm 31^{a}$} & \multirow{2}{*}{$90 \pm 15^{\mathrm{d}}$} & n.d. & - \\
\hline & $\mathrm{F}$ & 18 & & & $127,3 \pm 85,6^{\mathrm{a}}$ & & & & - & $47,1 \pm 12,2^{\mathrm{a}, \mathrm{b}}$ \\
\hline \multirow{2}{*}{ ESC } & M & 13 & \multirow{2}{*}{$31,3 \pm 17,6^{\mathrm{e}}$} & \multirow{2}{*}{$1433 \pm 416^{b}$} & $85,8 \pm 46,6^{\mathrm{a}}$ & \multirow{2}{*}{$7,0 \pm 4,8^{a}$} & \multirow{2}{*}{$126 \pm 59^{\mathrm{c}, \mathrm{d}}$} & \multirow{2}{*}{$67 \pm 11^{c}$} & $213,4 \pm 212,7$ & - \\
\hline & $\mathrm{F}$ & 17 & & & $118,0 \pm 50,5^{\mathrm{a}}$ & & & & - & $159,7 \pm 57,9^{c}$ \\
\hline \multirow{2}{*}{ RHO } & $\mathrm{M}$ & 14 & \multirow{2}{*}{$4,8 \pm 4,1^{\mathrm{a}, \mathrm{b}}$} & \multirow{2}{*}{$1509 \pm 426^{b}$} & $449,4 \pm 156,1^{b}$ & \multirow{2}{*}{$10,9 \pm 7,7^{\mathrm{a}}$} & \multirow{2}{*}{$117 \pm 46^{\mathrm{c}, \mathrm{d}}$} & \multirow{2}{*}{$50 \pm 11^{b}$} & $70,3 \pm 39,1$ & - \\
\hline & $\mathrm{F}$ & 16 & & & $613,1 \pm 122,6^{b}$ & & & & - & $111,2 \pm 129,2^{b, c}$ \\
\hline \multirow{2}{*}{ VIL } & $M$ & 20 & \multirow{2}{*}{$2,1 \pm 3,2^{\mathrm{a}}$} & \multirow{2}{*}{$1585 \pm 222^{b}$} & $552,2 \pm 170,0^{b}$ & \multirow{2}{*}{$38,8 \pm 15,3^{\mathrm{b}, \mathrm{c}}$} & \multirow{2}{*}{$100 \pm 50^{\mathrm{b}, \mathrm{c}, \mathrm{d}}$} & \multirow{2}{*}{$32 \pm 9^{a}$} & n.d. & - \\
\hline & $\mathrm{F}$ & 10 & & & $434,0 \pm 219,0^{b}$ & & & & - & $40,7 \pm 18,5^{\mathrm{a}, \mathrm{b}}$ \\
\hline \multirow{2}{*}{ VDV } & M & 12 & \multirow{2}{*}{$7,2 \pm 6,3^{\mathrm{b}, \mathrm{c}}$} & \multirow{2}{*}{$1024 \pm 167^{\mathrm{a}}$} & $103,6 \pm 60,1^{\mathrm{a}}$ & $252+117 \mathrm{~b}$ & $66+21$ a,b & $Q 6+Q^{d}$ & n.d. & - \\
\hline & $\mathrm{F}$ & 12 & & & $104,7 \pm 70,7^{\mathrm{a}}$ & 25 & & & - & $39,2 \pm 18,5^{\mathrm{a}}$ \\
\hline VDF & $\mathrm{M}$ & 10 & & $12+x-2 \cdot 1$ & $108,9 \pm 68,6^{\mathrm{a}}$ & & & & n.d. & - \\
\hline VDF & $\mathrm{F}$ & 14 & $1 \pm 17$ & $1386 \pm 256^{\circ}$ & $104,1 \pm 53,7^{\mathrm{a}}$ & \pm 9 & $7 / \pm$ & 102 & - & $89,0 \pm 64,2^{\text {a,b,c }}$ \\
\hline
\end{tabular}


Table 5. Morphological parameters for three-spined stickleback caught at the different sampling sites. Data are reported as mean \pm standard deviation. Values not sharing a common letter within a parameter are statistically different from each other (ANOVA followed by Sidak test, $\mathrm{p}<0.05)$.

\begin{tabular}{|c|c|c|c|c|c|}
\hline Sites & Sex & Number & HSI & GSI & $\mathrm{CF}$ \\
\hline \multirow{2}{*}{ REV } & $\mathrm{M}$ & 15 & \multirow{2}{*}{$4.5 \pm 1.5^{\mathrm{a}}$} & $1.8 \pm 0.5^{c}$ & \multirow{2}{*}{$0.85 \pm 0.09^{a}$} \\
\hline & $\mathrm{F}$ & 15 & & $1.5 \pm 0.4^{\mathrm{c}}$ & \\
\hline \multirow{2}{*}{ LEZ } & $\mathrm{M}$ & 12 & \multirow{2}{*}{$2.4 \pm 0.7^{b, c}$} & $0.7 \pm 0.5^{\mathrm{a}}$ & \multirow{2}{*}{$0.85 \pm 0.09^{a}$} \\
\hline & $\mathrm{F}$ & 18 & & $0.6 \pm 0.5^{\mathrm{a}}$ & \\
\hline \multirow{2}{*}{ ESC } & $\mathrm{M}$ & 13 & \multirow{2}{*}{$2.9 \pm 1.2^{b}$} & $1.1 \pm 0.3^{\mathrm{a}, \mathrm{b}}$ & \multirow{2}{*}{$1.00 \pm 0.11^{\mathrm{b}}$} \\
\hline & $\mathrm{F}$ & 17 & & $1.3 \pm 0.4^{\mathrm{a}, \mathrm{b}}$ & \\
\hline \multirow{2}{*}{ RHO } & $\mathrm{M}$ & 14 & \multirow{2}{*}{$3.8 \pm 0.9^{\mathrm{a}}$} & $1.7 \pm 0.3^{\mathrm{b}, \mathrm{c}}$ & \multirow{2}{*}{$0.99 \pm 0.17^{b}$} \\
\hline & $\mathrm{F}$ & 16 & & $1.8 \pm 0.6^{\mathrm{b}, \mathrm{c}}$ & \\
\hline \multirow{2}{*}{ VIL } & M & 20 & \multirow{2}{*}{$3.0 \pm 1.0^{b}$} & $2.0 \pm 0.5^{c}$ & \multirow{2}{*}{$1.00 \pm 0.12^{b}$} \\
\hline & $\mathrm{F}$ & 10 & & $1.9 \pm 0.5^{c}$ & \\
\hline \multirow{2}{*}{ VDV } & M & 12 & \multirow{2}{*}{$2.0 \pm 0.4^{\mathrm{c}}$} & $1.2 \pm 0.5^{b}$ & \multirow{2}{*}{$0.85 \pm 0.11^{a}$} \\
\hline & $\mathrm{F}$ & 12 & & $1.7 \pm 0.8^{b}$ & \\
\hline \multirow{2}{*}{ VDF } & $\mathrm{M}$ & 10 & \multirow{2}{*}{$2.0 \pm 0.5^{c}$} & $1.4 \pm 0.9^{\mathrm{b}, \mathrm{c}}$ & \multirow{2}{*}{$0.77 \pm 0.11^{\mathrm{a}}$} \\
\hline & $\mathrm{F}$ & 14 & & $1.5 \pm 0.9^{\mathrm{b}, \mathrm{c}}$ & \\
\hline
\end{tabular}


Table 6. Taxonomic classification and theoretical abundance, determined using the method of (Carle and Strub, 1978), of fish caught at different sampling sites. Fish-Based Index and associated class were determined according to the method of (Oberdorff et al., 2002).

\begin{tabular}{|c|c|c|c|c|c|c|c|}
\hline & REV & LEZ & ESC & RHO & VIL & VDV & VDF \\
\hline Anguilla anguilla & & 102 & & & & 24 & 86 \\
\hline Rhodeus sericeus & & & 22 & & & & \\
\hline Abramis brama & 1 & & 3 & & & & \\
\hline Esox lucius & 1 & & 1 & & & & \\
\hline Carassius carassius & 40 & & & & & & \\
\hline Cyprinus carpio carpio & 5 & & 2 & & & & \\
\hline Cottus gobio & & 124 & 2 & & 742 & 141 & 47 \\
\hline Leuciscus cephalus & 1 & & 1 & & 16 & & \\
\hline Gasterosteus aculeatus & 665 & 40 & 39 & 103 & 136 & 2 & 51 \\
\hline Pungitius pungitius & & 8 & & & & & 322 \\
\hline Rutilus rutilus & 140 & & 206 & 8 & 10 & & \\
\hline Gobio gobio & 44 & & 23 & 210 & 1 & & \\
\hline Lampetra planeri & & 10 & & & 4 & & \\
\hline Barbatula barbatula & 56 & & 1 & 311 & 527 & & \\
\hline Perca fluviatilis & 7 & 1 & 8 & & 4 & & \\
\hline Lepomis gibbosus & 4 & & 7 & & & & \\
\hline Pseudorasbora parva & & & 1 & & & & \\
\hline Scardinius erythrophthalmus & 44 & & & & & & \\
\hline Sander lucioperca & & & 1 & & & & \\
\hline Tinca tinca & 10 & & & & & & \\
\hline Salmo trutta fario & & 87 & & 2 & 6 & 4 & \\
\hline Phoxinus phoxinus & & & & & 52 & & \\
\hline FBI & 43.17 & 12.98 & 18.49 & 20.07 & 14.72 & 3.73 & 20.41 \\
\hline FBI class & 5 & 2 & 3 & 3 & 2 & 1 & 3 \\
\hline
\end{tabular}

